\title{
Effect of wheat straw and FYM on growth and reproduction of Eisenia fetida during vermicomposting
}

\author{
Shilpa Panjgotra*, G. K. Sangha ${ }^{1}$, Sandeep Sharma $^{2}$ and J. K. Kondal ${ }^{3}$ \\ ${ }^{* 1,3}$ Department of Zoology, College of Basic Sciences \& Humanities, Punjab Agriculture University (PAU), \\ Ludhiana-141004 (Punjab), INDIA \\ ${ }^{2}$ Department of Soil Science, College of Agriculture, Punjab Agriculture University, Ludhiana-141004 (Punjab), \\ INDIA \\ *Corresponding author E-mail: shilpapau@gmail.com \\ Received: March 18, 2016; Revised received: August 12, 2016; Accepted: November 27, 2016
}

\begin{abstract}
Rapid growth of urbanization and industrialization has led to generation of large quantities of wastes. Major portion of organic waste is burned or dumped, creating huge amount of pollutants. The best possible alternative to reduce these pollutants is through vermicomposting. This experiment was done to investigate the effect of wheat straw and FYM (farm yard manure) in different combinations of 1:1, 1:1/2 and control on biological parameters viz., mean initial weight (mg/worm), maximum weight achieved (mg/worm), net weight gain (mg/worm), growth rate $(\mathrm{mg} /$ worm/day), duration of life cycle (in days), initiation of cocoon production (in days), total number of cocoons produced (in days), initiation of hatching (in days), hatching per cocoon, cocoons produced per worm, cocoons produced per day and period for vermicomposting along with physico-chemical parameters of vermicompost viz., $\mathrm{pH}$, EC $\left(\mathrm{dS} \mathrm{m}^{-1}\right)$, nitrogen $(\mathrm{kg} / \mathrm{ha})$, phosphorous $(\mathrm{kg} / \mathrm{ha})$, potassium $(\mathrm{kg} / \mathrm{ha})$ and organic carbon $(\%)$. The study revealed that maximum period required for Eisenia fetida to complete its life cycle was $59.33 \pm 0.39$ days in $1: 1$ combination (wheat straw: FYM), 62.33 0.29 days in 1:1/2 combination (wheat straw: FYM) and $66 \pm 0.77$ days in control. Net weight gain and growth rate was higher in 1:1 combination. Initiation of cocoon production (23.66 \pm 0.14$)$ and hatching $(21 \pm 0.25)$ was recorded to be early in $1: 1$ combination. Total number of cocoons produced, cocoons produced per day and cocoons produced per worm was also higher in 1:1 combination. At the end, ready vermicompost showed decreased level of $\mathrm{pH}, \mathrm{EC}, \mathrm{OC}$ and increased level of nitrogen, phosphorus and potassium content. The maximum significant results were obtained in 1:1 combination. In 1:1 combination decrease in $\mathrm{pH}$, EC and $\mathrm{OC}$ was $11.09 \%, 41.45 \%$ and $59.55 \%$, respectively and increase in nitrogen, phosphorous and potassium was $250.84 \%$, $216.12 \%$ and $168.75 \%$, respectively. Results indicate that $E$. fetida in 1:1 combination is more suitable for bioconversion of organic residues into useful manure due to its high growth, reproduction and nutritive potential.
\end{abstract}

Keywords: Cow dung, Earthworms, Organic waste, Vermiculture, Waste management

\section{INTRODUCTION}

Generation of organic agro-wastes has increased at an unprecedented rate around the globe, because of increased food grain production to feed the population, leading to disposal problems (Grewal et al., 2016). The major quantity of wastes generated from agricultural resources are sugarcane baggase, paddy and wheat straw and husk, wastes of vegetables, food products, jute fibre, groundnut shell, coconut husk and cotton stalk etc (Viji and Neelanarayanan, 2016). So, it is an emergent need for the safe handling of abundant production of agro wastes (Steven et al., 2009). India produces around 3000 MT (million tonnes) of organic waste annually (Bhardwaj 2010) and according to conservative estimates, around 600-700 MT of agricultural wastes (including 272 MT of crop residues) is available in India every year, but most of it is unutilized (Alok et al., 2008; Suthar, 2009) for sustainable prac- tices. It has been estimated that organic resources available in the country alone can produce not less than $20 \mathrm{MT}$ of plant nutrients (nitrogen, phosphorous and potassium) (Kandan and Subbulakshmi, 2015). Such, large quantities of organic wastes produced worldwide have necessitated researchers to develop appropriate waste recycling technologies in order to protect and preserve the environment. Recycling of these large amount of agro-waste in an eco-friendly manner helps in contribution towards sustainable agricultural practices (Suramaythangkoor and Gheewala, 2008). Earthworms are one of the major soil macro invertebrates and are known for their contributions to soil formation and turnover with their widespread global distribution (Norbu, 2002). It plays a significant role in decomposition due to their symbiotic relationship with bacteria. As earthworms ingest and digest organic matter, they also take in microorganisms and metabolize them. When the organic material passes 
through the gut of the earthworm it again increases the surface area of the material so that the microorganisms can break it down further. The undigested materials or castings, are fertile and rich in nutrients readily available to plants (Hansen, 2007). Vermicomposting is one of the most important tools in the campaign to recycle agricultural wastes as biofertilizers (Singh et al., 2013). Many earthworm populations have been reported to convert different kinds of wastes into rich nutrient biofertilizers (Suthar, 2007, Chauhan and Singh, 2013). Eisenia fetida is the most suitable species for vermicomposting due to its short life cycle, high reproduction and regeneration rate. It can survive on a variety of degradable organic wastes like various combinations of animal, agro and kitchen wastes (Garg et al., 2005). For this reason, different combinations of cattle dung (sheep, horse, goat, buffalo) with agro-wastes (vegetable waste, wheat bran, rice bran, gram bran, barley bran, straw) have been used as an effective tool for vermicomposting (Singh et al., 2013). Livestock dung has been used as the main substrate for growth and development of E. fetida; some agricultural wastes with it were also used for the improvement of the growth and reproduction of the earthworm (Chauhan and Singh, 2013). Wheat is an important cereal crop of Punjab which also generates large amounts of post processing wastes. Hence, these post processing wastes of wheat can be used as organic substrate in vermicomposting (Hassan and Sokhi, 2002). The growth and reproduction of the earthworm are significantly affected by various factors such as waste type, temperature, density, moisture, chemical complexity, bulky material, and earthworm species during vermicomposting (Yadav and Garg, 2010). Consequently, the effect of different combinations of wheat wastes and FYM on the growth and reproduction of E. fetida along with evaluation of the vermicomposting process for stability (maturity) and quality is based on physical as well as chemical parameters of the final product was studied so that the most suitable combination of wastes be used for sustainable crop production. Therefore, the present study was undertaken to explore the composting potential of $E$. fetida for eco-friendly management of wheat wastes and analyse the potential nutrients in the prepared vermicompost.

\section{MATERIALS AND METHODS}

Culturing of the earthworm: The stock of earthworms, E. fetida was maintained in animal dung substrate obtained from dairy farm of Guru Angad Dev University of Veterinary and Animal Sciences, Ludhiana. The dung was stabilised and placed in plastic tubs in laboratory of Department of Zoology, Punjab Agricultural University, Ludhiana. The stock was watered regularly and otherwise maintained for culturing of earthworms. The stock was maintained under optimum temperature $\left(15-28^{\circ} \mathrm{C}\right)$, moist $(60-65 \%)$ and shady conditions. Juvenile worms were randomly picked from this stock for experiments (Grewal et al., 2016).

Collection of cattle waste: The fresh waste of cow (FYM) was collected from Dairy Farm of Guru Angad Dev Veterinary and Animal Sciences University, Ludhiana. Pre-composting of agro-waste and animal dung was done for 15 days is essential to avoid the death of the worm. The pre-composting was done in room temperature with regular watering and maintained the moisture between 60-65\%.

Collection of agro-waste (Wheat straw): The organic waste (Wheat Straw) used as substrate was collected from crop fields of Punjab Agricultural University, Ludhiana and nearby fields of district Ludhiana. All the samples were kept at room temperature.

Experimental design: A quantity of $750 \mathrm{~g}$ of organic waste (Wheat straw) with FYM in different combinations i.e. $1: 1$ and $1: 1 / 2$ were each placed in plastic trays of size $22 \times 17.5 \times 5 \mathrm{~cm}$. Twenty eight, juvenile earthworms were collected from the stock culture and released into each plastic tray. The moisture content was maintained at approximately $65 \%$ and temperature was recorded regularly. Experimental bedding was kept in triplicate for each treatment along with control (FYM). All beddings were allowed for thermal stabilization, initiation of microbial degradation and softening of waste. Twenty juvenile, earthworms (having individual live weight of 210-226 mg) were collected from the stock culture and released into experimental and control plastic trays. The vermicomosting beds were turned over manually every $24 \mathrm{~h}$ for 2 weeks in order to eliminate volatile substances.

Growth and reproduction analysis: Growth and reproduction of E. fetida in control and experimental trays of different combinations of 1:1 (wheat straw: FYM) and 1:1/2 (wheat straw and FYM) was measured after every week. Biomass gain, development and initiation of cocoon production were recorded up to 11 weeks in both the combinations along with the control. One freshly laid cocoon was kept per petri dish $(8.6 \times 8.6 \mathrm{~cm})$ with the same substrate in which their parents were reared. Cocoons were observed everyday to record incubation period, hatching, hatching per cocoon, total number of cocoons produced during vermicomposting, cocoons produced per day and per worm along with duration of life cycle was also noted.

Physicochemical analysis: The physicochemical parameters of the initial substrate material and vermicompost were analysed by using standard methods. The $\mathrm{pH}$ and EC determined using a double distilled water suspension of each waste in the ratio of $1: 10(\mathrm{w} /$ v) and measured using digital $\mathrm{pH}$ and $\mathrm{EC}$ meter. Organic carbon (OC) content was determined by partial oxidation method (Walkey and Black, 1934). Total kjeldahl nitrogen (TKN) was measured by Microkjeldahl method as described by Jackson (1958). Total phosphorous (TP) analysed using the colorimetric 
method with molybdenum in sulphuric acid (Jackson, 1967). Total potassium (TK) determined by flame photometer (Jackson, 1967).

Statistical analysis: Analysis of variance was used to determine the significant difference in different combinations of wheat straw and FYM along with the control.

\section{RESULTS}

Biomass increase (Growth) in different vermibeds: The earthworm biomass gain varied among different feed mixtures. At the start of the experiment, weight of inoculated earthworms ranged from $210.7 \pm 1.55$ to $226.8 \pm 1.42 \mathrm{mg} /$ worm. There was significant increase in overall growth of $E$. fetida in 1:1 combination as compared to $1: 1 / 2$ combination and the control in the experimental set up for 11 weeks. After 11 weeks $E$. fetida achieved maximum weight gain in 1:1 combination of wheat straw and FYM i.e. $931.5 \pm 2.48 \mathrm{mg} /$ worm, while $868.7 \pm 1.98 \mathrm{mg} /$ worm in $1: 1 / 2$ combination and $780.6 \pm 2.26 \mathrm{mg} /$ worm in control (only FYM). There was significant $(\mathrm{p}<0.05)$ increase in net weight gain (net biomass increase) of earthworms i.e. $720.8 \pm 2.43 \mathrm{mg} /$ worm in $1: 1$ combination as compared to $1: 1 / 2$ combination i.e. $649.4 \pm 1.91 \mathrm{mg} /$ worm and control i.e. $553.2 \pm 2.97 \mathrm{mg} /$ worm. The growth rate (mg/worm/day) was non-significant among the two combinations and the control (Table 1).

Reproduction performance in different vermibeds: The two different combinations of wheat straw with FYM and control resulted in significant differences in reproduction parameters of the earthworm Eisenia fetida (Table 2). The duration of life cycle was observed to be shortest in 1:1 combination i. e. $59.3 \pm 0.39$ days as compared to $1: 1 / 2$ combination i. e. $62.33 \pm 0.29$ days and in the control (only FYM) i. e $66 \pm 0.77$ days. Similarly, initiation of cocoon production was early in 1:1 combination ( $23.66 \pm 0.14$ days) followed by $1: 1 / 2$ combination $(24.66 \pm 0.29$ days $)$ and control ( $27 \pm 0.25$ days). Initiation of hatching was also noted to be early in 1:1 combination ( $21 \pm 0.25$ days) followed by $1: 1 / 2$ combination ( $23.66 \pm 0.14$ days) and than in control $(26 \pm 0.39$ days). On the other hand, hatching per cocoon was non-significant among all the vermibeds ranging between $(1.33 \pm 0.14)$ 1:1 combination, $(1.33 \pm 0.14) 1: 1 / 2$ combination and $(1.66 \pm 0.149)$ control. The total number of cocoons produced was significantly higher in 1:1 combination $(51.60 \pm 0.29)$ as compared to $1: 1 / 2$ combination $(47.33 \pm 0.39)$ and control (44.66 \pm 0.53$)$. Similarly, cocoons produced per day were higher in $1: 1$ combination $(0.54 \pm 0.0029)$, followed by $1: 1 / 2$ combination $(0.46 \pm 0.0039)$ and control $(0.40 \pm 0.005)$, whereas, cocoons produced per worm revealed non-significant differences when compared among the combinations i.e. $2.58 \pm 0.014(1: 1$ combination), $2.28 \pm 0.056$ (1:1/2 combination) and the control $(2.23 \pm 0.026)$.

Vermicomposting efficiency of earthworms: The process of vermicomposting by E. fetida was completed earlier in 1:1 combination i.e. in 93 days. On the other hand, the vermicomposting was completed in 102 days in $1: 1 / 2$ combination and in 109 days in the control (Table 2).

Physicochemical analysis: The physical properties of initial feed mixture were changed after vermicomposting. During vermicomposting, the final $\mathrm{pH}$ of all the vermibeds was non-significantly decreased with respect to the initial feed mixture (Table 3). The maximum lowest $\mathrm{pH}$ was observed in $1: 1$ combination of wheat straw and FYM as $6.65 \pm 0.029$ which is suitable for earthworm development. During the study period, the electrical conductivity (EC) of initial feed mixtures ranged from $1.78 \pm 0.01$ to $2.48 \pm 0.01 \mathrm{dS} / \mathrm{m}^{-1}$; while in the final vermicompost, a significant decrease was observed which ranged from $1.53 \pm 0.005$ to $1.04 \pm 0.008$ $\mathrm{dS} / \mathrm{m}^{-1}$. The significantly lowest $\mathrm{pH}$ and EC was observed in the final vermicompost of $1: 1$ combination of wheat straw and FYM as compared to $1: 1 / 2$ and control. During the process of vermicomposting, there was significant increase in different biochemical parameters such as TKN, TP, TK and significant decrease in OC in all the beddings of the final vermicompost as compared to the initial feed mixtures (Table 4). Maximum significant results were observed in 1:1 combination as compared to $1: 1 / 2$ combination and control. In $1: 1$ combination the significant increase in TKN, TP and TK was $2.07 \pm 0.02 \%, 0.98 \pm 0.012 \%$ and $2.58 \pm 0.012$ $\%$, respectively. The decrease in OC content was maximum in $1: 1$ combination i.e. $10.59 \pm 0.08 \%$.

\section{DISCUSSION}

In the present study, effort has been made to evaluate the recycling process of agro-waste (wheat straw) and FYM as well as growth and reproduction patterns of $E$. fetida during the process of vermicomposting. The different combinations of substrate material amended with farm yard manure used in this study include 1:1 combination (wheat straw and FYM), 1:1/2 combination and control. The different combinations have different palatability, particle size, microbial structure and chemical composition. Farm yard manure is high quality material with fast decomposition rates, while wheat straw residues are high quality material but with slow decomposition rates due to high $\mathrm{C}-\mathrm{N}$ ratio. Different combinations and control vermibeds showed variations in growth and reproduction parameters. The earthworm showed maximum bio-potential in 1:1 combination. The difference in growth rate among different feed mixtures seems to be closely related to feed quality. According to Fayolle et al. (1997) among the different variables necessary for earthworm production, the type of food seems to be most important. The excellent growth rate in 1:1 combination of wheat straw and FYM may be attributed to its palatability and more acceptability as food by worms. Moreover, beddings 
Table 1. Growth rate of Eisenia fetida in different combinations of wheat straw agro-waste and FYM during vermicomposting (September-December 2014)

\begin{tabular}{|c|c|c|c|c|c|}
\hline Combinations & $\begin{array}{l}\text { Mean initial weight } \\
\text { (mg/worm) }\end{array}$ & $\begin{array}{l}\text { Maximum weight } \\
\text { achieved (mg/worm) }\end{array}$ & $\begin{array}{l}\text { Net weight gain } \\
\text { (mg/worm) }\end{array}$ & $\begin{array}{l}\text { Growth rate } \\
\text { worm/day) }\end{array}$ & (mg/ \\
\hline Control (FYM) & $226.8 \pm 1.42$ & $780.6 \pm 2.26^{\mathrm{a}}$ & $553.2 \pm 2.97^{\mathrm{a}}$ & $7.28 \pm 0.07^{\mathrm{ab}}$ & \\
\hline $\begin{array}{l}\text { 1:1 Combination } \\
\text { (Wheat straw: FYM) }\end{array}$ & $210.7 \pm 1.55$ & $931.5 \pm 2.48^{\mathrm{a}}$ & $720.8 \pm 2.43^{\mathrm{a}}$ & $9.35 \pm 0.03^{\mathrm{ab}}$ & \\
\hline $\begin{array}{l}1: 1 / 2 \quad \text { Combination } \\
\text { (Wheat straw: } F Y M)\end{array}$ & $219.3 \pm 2.11$ & $868.7 \pm 1.98^{\mathrm{a}}$ & $649.4 \pm 1.91^{\mathrm{a}}$ & $8.43 \pm 0.02^{\mathrm{ab}}$ & \\
\hline
\end{tabular}

Values are Mean \pm SE of three replicates, the values with superscript(a) shows significant difference between the two combinations along with control and superscript $(\mathrm{ab})$ shows non-significant results $(\mathrm{p}<0.05)$.

Table 2. Effect of different combinations of wheat straw and FYM on the reproduction of Eisenia fetida during vermicomposting (September-December 2014).

\begin{tabular}{llll}
\hline Reproduction Parameters & Control (FYM) & $\mathbf{1 : 1}($ Wheat straw: FYM) & $\mathbf{1 : 1 / 2}$ (Wheat straw: FYM) \\
\hline $\begin{array}{l}\text { Period for vermicomposting } \\
\text { (In days) }\end{array}$ & 109 Days $^{\mathrm{a}}$ & $93 \mathrm{Days}^{\mathrm{a}}$ & 102 Days $^{\mathrm{a}}$ \\
$\begin{array}{l}\text { Duration of life cycle } \\
\text { (In days) }\end{array}$ & $66 \pm 0.77^{\mathrm{a}}$ & $59.3 \pm 0.39^{\mathrm{a}}$ & $62.33 \pm 0.29^{\mathrm{a}}$ \\
$\begin{array}{l}\text { Initiation of cocoon production } \\
\text { (In days) }\end{array}$ & $27 \pm 0.25^{\mathrm{a}}$ & $23.66 \pm 0.14^{\mathrm{a}}$ & $24.66 \pm 0.29^{\mathrm{a}}$ \\
Total number of cocoons produced & $44.66 \pm 0.53^{\mathrm{a}}$ & $51.60 \pm 0.29^{\mathrm{a}}$ & $47.33 \pm 0.39^{\mathrm{a}}$ \\
Initiation of hatching & $26 \pm 0.39^{\mathrm{a}}$ & $21 \pm 0.25^{\mathrm{a}}$ & $23.66 \pm 0.14^{\mathrm{a}}$ \\
(In days) & $1.66 \pm 0.14^{\mathrm{ab}}$ & $1.33 \pm 0.14^{\mathrm{ab}}$ & $1.33 \pm 0.14^{\mathrm{ab}}$ \\
Hatching per cocoon & $2.23 \pm 0.026^{\mathrm{ab}}$ & $2.58 \pm 0.014^{\mathrm{ab}}$ & $2.28 \pm 0.056^{\mathrm{ab}}$ \\
Cocoons produced per worm & $0.40 \pm 0.005^{\mathrm{a}}$ & $0.54 \pm 0.0029^{\mathrm{a}}$ & $0.46 \pm 0.0039^{\mathrm{a}}$ \\
\hline Cocoons produced per day & &
\end{tabular}

Values are Mean \pm SE of three replicates, the values with superscript(a) shows significant difference between the two combinations along with control and superscript $(\mathrm{ab})$ shows non-significant $\operatorname{results}(p<0.05)$.

Table 3: Physical parameters of initial feed mixture and the final vermicompost of different combinations of wheat straw and FYM (September-December 2014).

\begin{tabular}{|c|c|c|c|c|}
\hline \multirow{2}{*}{ Treatments } & \multicolumn{2}{|r|}{$\mathrm{pH}$} & \multicolumn{2}{|c|}{ EC } \\
\hline & IM & FV & IM & FV \\
\hline FYM & $8.02 \pm 0.008$ & $7.33 \pm 0.033^{\mathrm{ab}}$ & $2.48 \pm 0.01$ & $1.53 \pm 0.005^{\mathrm{a}}$ \\
\hline $\begin{array}{l}\text { 1:1 Combination } \\
\text { (Without Earthworms) }\end{array}$ & $7.99 \pm 0.096$ & $7.01 \pm 0.058^{\mathrm{ab}}$ & $2.01 \pm 0.01$ & $1.22 \pm 0.057^{\mathrm{a}}$ \\
\hline $\begin{array}{l}1: 1 / 2 \text { Combination } \\
\text { (Without Earthworms) }\end{array}$ & $7.91 \pm 0.012$ & $7.06 \pm 0.012^{\mathrm{ab}}$ & $2.09 \pm 0.020$ & $1.31 \pm 0.017^{\mathrm{a}}$ \\
\hline $\begin{array}{l}\text { 1:1 Combination } \\
\text { (With Earthworms) }\end{array}$ & $7.48 \pm 0.006$ & $6.65 \pm 0.029^{\mathrm{ab}}$ & $1.78 \pm 0.01$ & $1.04 \pm 0.008^{\mathrm{a}}$ \\
\hline $\begin{array}{l}\text { 1:1/2 Combination } \\
\text { (With Earthworms) }\end{array}$ & $7.63 \pm 0.003$ & $6.84 \pm 0.025^{\mathrm{ab}}$ & $2.04 \pm 0.008$ & $1.13 \pm 0.008^{\mathrm{a}}$ \\
\hline
\end{tabular}

Values are Mean $\pm \mathrm{SE}$ of three replicates, the values with superscript (a) shows significant difference between the two combinations along with control and superscript (ab) shows non-significant results $(p<0.05)$. (IM- Initial Mixture, FV- Final Vermicompost).

that exhibited better worm growth probably had good supply of organic matter from wheat straw, as the ratio of organic matter (wheat straw) in 1:1 combination was higher than in 1:1/2 combination and was least in control where no wheat straw was present. The results suggest that the quality of substrate material used in this study might be responsible for observed differences in maximum weight gain. Hence, the significant values obtained in 1:1 combination may be due to the presence of higher amount of organic matter during vermicomposting of wheat straw.

The reproduction pattern of earthworms was different among different combinations, depending on the quality of the worm feed. Earlier studies have also revealed variations in reproduction parameters of Eisenia fetida with respect to nature of the waste materials (Gargand Kaushik, 2005, Suthar et al., 2005). An increase in the number of earthworms (22 to 36 folds) and (2.2 to 3.9 
Table 4. Chemical parameters of initial feed mixture and the final vermicompost of different combinations of wheat straw and FYM (September-December 2014).

\begin{tabular}{lcccccccc}
\hline \multirow{2}{*}{ Treatments } & \multicolumn{2}{c}{ TKN \% } & \multicolumn{2}{c}{ TP \% } & \multicolumn{2}{c}{ TK \% } & \multicolumn{2}{c}{ TOC \% } \\
\cline { 2 - 9 } & $\mathbf{I M}$ & FV & IM & FV & IM & FV & IM & FV \\
\hline $\begin{array}{l}\text { FYM } \\
\text { 1:1 Combination }\end{array}$ & $0.36 \pm 0.03$ & $0.67 \pm 0.01$ & $0.11 \pm 0.08$ & $0.29 \pm 0.01$ & $0.51 \pm 0.025$ & $0.88 \pm 0.04$ & $16.33 \pm 0.08$ & $11.91 \pm 0.14$ \\
(Without Earthworms) & $0.50 \pm 0.01$ & $0.83 \pm 0.08$ & $0.24 \pm 0.04$ & $0.47 \pm 0.02$ & $0.98 \pm 0.008$ & $1.35 \pm 0.08$ & $24.34 \pm 0.06$ & $18.74 \pm 0.08$ \\
$\begin{array}{l}1: 1 / 2 \text { Combination } \\
\text { (Without Earthworms) }\end{array}$ & $0.39 \pm 0.08$ & $0.78 \pm 0.01$ & $0.21 \pm 0.03$ & $0.39 \pm 0.08$ & $0.86 \pm 0.02$ & $1.28 \pm 0.08$ & $21.96 \pm 0.01$ & $15.83 \pm 0.06$ \\
$\begin{array}{l}\text { 1:1 Combination } \\
\text { (With Earthworms) }\end{array}$ & $0.59 \pm 0.08$ & $2.07 \pm 0.02$ & $0.31 \pm 0.03$ & $0.98 \pm 0.02$ & $0.96 \pm 0.08$ & $2.58 \pm 0.02$ & $25.96 \pm 0.01$ & $10.59 \pm 0.08$ \\
$\begin{array}{l}\text { 1:1/2 Combination } \\
\text { (With Earthworms) }\end{array}$ & $0.48 \pm 0.06$ & $1.52 \pm 0.01$ & $0.26 \pm 0.08$ & $0.74 \pm 0.08$ & $0.90 \pm 0.06$ & $2.45 \pm 0.02$ & $21.66 \pm 0.66$ & $8.20 \pm 0.02$ \\
\hline
\end{tabular}

Values are Mean \pm SE of three replicates, All the values shows significant difference between the two combinations along with control $(p<0.05)$. (IM- Initial Mixture, FV- Final Vermicompost).

times) in total biomass was reported by Elvira et al. (1998) when paper mill sludge was combined with cattle wastes. In present investigation, beddings contained wheat straw, mixed with FYM in different combinations, having comparatively different nutrient profiles. Higher the amount of organic matter present in the vermibed, higher is the reproduction rate of Eisenia fetida. It might be due to the presence of hemicellulose and high $\mathrm{C} / \mathrm{N}$ ratio in wheat straw. Hemicellulose, lignin and cellulose are the main components of wheat straw (Pan and Sano, 2005). The combination of agro and kitchen wastes with cattle dung provides a suitable environment for better growth and development of Eisenia fetida (Nath et al., 2009). According to Fayolle et al. (1997) feeding source played an important role in cocoon production patterns in Dendro baenaveneta. Similarly change in biomass and cocoon production of Perionyx sonsbarious affected by different feeding material quality have been reported by Suthar (2007). According to Loh et al. (2005) biomass gain and cocoon production by E. fetida have been recorded to be more in cattle wastes as compared to goat wastes.

The reproduction behaviour of earthworms could be interpreted with respect to the chemical, physical and biological properties of waste material. Earlier studies have revealed that microbial population of substrate material clearly influences the concentration of metabolites that consequently affect biological activities of earthworms (Fayolle et al., 1997). In past studies cocoon hatching success has been studied extensively in terms of their environmental needs (temperature, moisture, $\mathrm{pH}$ etc.). In the present study, different combinations of wheat straw and FYM enhances growth and reproduction of Eisenia fetida. Some degree of optimal chemical composition of substrate material (N-content, $\mathrm{C}$-to-N ratio, concentration of polyphenols and related compounds) may be beneficial for rapid vermiculture. Better results of biomass as well as reproduction potential of composting earthworm species (Eisenia feti$d a$ ) could be due to physio-chemical properties, palata- bility, and microbial composition of substrate materials. The data revealed that quality of the waste material in different combinations used for vermiculture influenced the biomass production and reproduction performance of composting earthworms. Appropriate substrate and/or feeding material in different combinations for earthworm culture could optimize vermicomposting practices.

During vermicomposting, the final $\mathrm{pH}$ of all the vermibeds was decreased significantly with respect to the initial feed mixture which is suitable for earthworm development. There was a trend of the neutral $\mathrm{pH}$ in the final vermicompost (Singh et al., 2005). These changes in $\mathrm{pH}$ may be due to the degradation of organic solid wastes, and during this process, formation of fulvic acid (Chauhan and Singh, 2012), humic acid and ammonium ions occurred (Short et al., 1999). In the experiment, the electrical conductivity of initial feed mixture decreases significantly may be due to high organic matter loss consequently and release of different mineral salts. Garg et al. (2005) reported that there is $46 \%$ to $28.4 \%$ reduced EC in the final vermicompost, it is due to the increased rate of loss of organic matter, consequently release of different mineral salts. Singh et al. (2010) observed that EC significantly declined $(28.69 \%)$ in the final vermicompost during the management of bio sludge of the beverage industry. $\mathrm{EC}$ and $\mathrm{pH}$ are limiting factors for $E$. fetidagrowth and development (Edwards, 1998).

TKN level was also significantly increased in final vermicompost than initial mixture. Due to mineralization of organic matter during vermicomposting as well as by earthworms stabilized nitrogen excreta, mucus, enzyme and certain hormones are released (Tripathi and Bharadwaj 2004, Hobson, 2005). The TKN increase in the final vermicompost may be due to mineralization and addition of some byproduct or assimilatory product by the earthworm (Chauhan and Singh, 2012). In spite of all, the available $N$ content in the vermicompost depends on the combination of initial feed mixture. According to Kale et al. (1982), nitrogen content accumulated in the earthworm cast after the 
digestion of wastes by the earthworms. Earlier studies by Chauhan and Singh (2013) reports that total TKN content was significantly highest at $53.80 \%$ which increased $(12.48 \pm 0.03$ to $26.21 \pm 0.09 \mathrm{gm} / \mathrm{kg})$ in the final vermicompost of GWGr combination (goat dung + wheat straw + gram bran).

The TP content was significantly increased in the final vermicompost. The increase in total $\mathrm{P}$ may be due to the phosphorus mineralization by the earthworm. Lee (1992) suggested that unavailable phosphorus was converted in the earthworm intestine to an available form and also by solublization by the microorganism in their casts. This result was supported by Vinotha et al. (2000) as it is the major role of the microflora due to the increase of phosphatase activity. During vermicomposting, there was a significant increase $(11 \%$ to $83 \%$ ) in the total $\mathrm{K}$ in all the final vermicomposts. The total $\mathrm{K}$ increased in all vermibeds after 150 days (Suthar, 2007). Similar result was found in vermicomposting of sewage sludge by using red worm (Suthar, 2010). According to Barois and Lavelle (1986), symbiotic association of microorganism in earthworm gut and secreted mucus water helps in increasing the degradation of organic matter. The total nutrient content in the vermicompost for plant depends on the nature of the initial feed mixture, about 2.0 to 2.6 times (on a dry weight basis) in the final vermicompost. The phosphorus and potassium contents were 1.36 and 2.14 times, respectively, greater than the raw material for vermicomposting (Tripathi and Bhardwaj, 2004).

The OC content declined drastically from the substrate up to 90 days (Suthar, 2007). In all of the chemical parameters in the vermicompost, total OC was the most important for the growth and development of the earthworm which may be due to its use in the metabolism, thus a reduction in the final vermicompost. The organic content was lost in the form of $\mathrm{CO}_{2}$ by the earthworm activity, thus, also a decline from initial feed mixture as well as increase the stabilization process of waste. In the present study, the maximum significant decrease in organic carbon was observed in 1:1 combination i.e. $59.55 \%$. The studies conducted by Contreras-Ramos et al. (2004) also showed decreased TOC content of a resultant product after 60 days of vermicomposting period. The total OC reduction during vermicomposting was observed $24 \%$ to $60 \%$ in the different combinations of vermibed in an earlier research (Yadav and Garg, 2010). The significant reduction of total $\mathrm{OC}$ in $\mathrm{CWBr}$ (cow dung + wheat straw + barley bran) has been reported to be about 38\% (Chauhan and Singh, 2013).

\section{Conclusion}

In the present study, higher rate of growth and reproduction was recorded in 1:1 combination of wheat straw and FYM as compared to $1: 1 / 2$ combination and the control. A considerable amount of worm biomass and cocoons were produced in the two combinations. Moreover, the final vermicompost showed higher amount of TKN $(2.07 \pm 0.02 \%)$, TP $(0.98 \pm 0.02 \%)$, TK $(2.58 \pm 0.02 \%)$ content and decreased amount of OC content $(10.5 \pm 0.08 \%)$. The results suggest that wheat straw and FYM (1:1) can be used as an efficient culture media for large scale production of vermicompost for sustainable land restoration practices at low input basis.

\section{REFERENCES}

Aalok, A., Tripathi, A.K. and Soni, P. (2008). Vermicomposting: A Better option for organic solid waste management. J. Hum. Ecol., 24(1): 59- 64

Barois, I. and Lavelle, P. (1986). Changes in respiration rate and some physicochemical properties of a tropical soil during transit through Pontoscolex corethrurus (Glossoscolecidae, Oligochaeta). Soil. Biol. Biochem. 18:539-59

Bharadwaj, A. (2010). Management ofkitchen waste material through vermicomposting. Asian. J. Exp. Biol. Sci., 1 (1): $175-77$

Chauhan, H.K. and Singh, K. (2013). Effect of tertiary combinations of animal dung with agro-wastes on the growth and development of earthworm Eiseniafetida during organic waste management. Int. J. Rec. Org. Waste. Agri., 2:11

Chauhan, H.K. and Singh, K. (2012). Effect of binary combinations of buffalo, cow and goat dung with different agro-wastes on reproduction and development of earthworm Eisenia fetida(Haplotoxida: Lumbricidae). World. J. of Zoo., 7 (1):23-29

Contreras-Ramos, S.M., Escamilla-Silva, E.M., and Dendooven L., (2004). Vermicomposting of biosolids with cow manure and oat straw, Biol. Fer. Soil, 41(3):190198

Edwards, C.A., (1998). The use of earthworms in the breakdown and management of organic wastes - In: Edwards, C.A. (eds), Earthworm Ecology, St. Lucie

Elvira, C., Sampedro, L., Benitez, E. and Nogales, R. (1998). Vermicomposting of sludges from paper mill and dairy industries with Eiseniaandrei: A pilot scale study. Biores. Technol., 63:205-211

Fayolle, L., Mitchell, H., Cluzeau, D. and Stawiec, J. (1997). Influnence of temperature and food source on the life cycle of the earthworm Dendro baenaveneta (Oligochaeta). Soil. Biol. Biochem., 29:747-750

Garg, V.K., Chand, S., Chhillar, A., and Yadav, Y.K. (2005). Growth and reproduction of Eiseniafoetidain various animal wastes during vermicomposting. App. Ecol. Environ. Res., 3(2):51-59

Garg, V.K. and Kaushik, P. (2005). Vermistabilization of textile mill sludge spiked with poultry droppings by an epigeic earthworm Eisenia fetida. Biores. Technol., 96:1063-1071

Grewal, A., Hundal, S.S. and Sharma, S. (2016). Biomanagement of agro-origin wastes for value addition. $J$. Environ. Res. Develop., 10(4): 700-705

Hansen, D. (2007). Vermicomposting: innovative kitchen help. [Online] Available:http://www.dnr.mo.gov/env/ swmp/docs/vermicomposting.pdf (April, 12 2008).

Hassan, S.S. and Sokhi, J. (2002). Educational Back up An essential input for sustainable Aquaculture. In Sustaina- 
ble Aquaculture. (ed) Dirabondhu S, Qasimpp, S Z. Pp 139-144

Hobson, A.M., Fedrickson, J. and Dise, N. B. (2005). CH and $\mathrm{NO}$ from mechanically turned windrow and vermicomposting systems following in-vessel pretreatment. Waste.Manag., 4:345-352

Jackson, M.L. (1967). Soil Chemical Analysis, Prentice Hall of India Ltd. New Delhi

Jackson, M.L. (1958). Soil chemical analysis. Pranctice hall of India, New Delhi

Kale, R.D., Bano, K. and Krishnamoorthy, R.V. (1982): Potential of Perionyx excavatus for utilizing organic wastes. Pedobiologia, 23:419-425

Kandan, T. and Subbulakshmi., (2015). Chemical nutrient analysis of vermicompost and their effect on the growth of SRI Rice Cultivation. Int. J. Innov. Res. Sci. Engg. Technol., 4: 661-69

Lee, K.E., (1992). Some trends opportunities in earthworm researcher: Darwin's children. The future of our discipline. Soil. Biol. Biochem., 24:1765-1771

Loh, T.C., Lee, Y.C., Liang, J.B., and Tan, D. (2005). Vermicomposting of cattle and goat manures by Eisenia foetida and their growth and reproduction preference. Biores. Technol., 96:111-114

Nath, G., Singh, K., and Singh, D.K. (2009). Effect of different combinations of animal dung and agro/ kitchen wastes on growth and development of earthworm Eisenia foetida. Australian. J. Basic. App. Sci., 3: 35533556

Norbu, T. (2002). Pretreatment of municipal solid waste by windrow composting and vermicomposting. [Online] Available: http://www.faculty. ait.ac.th /visu/data/AITThesis /Master\%20Thesis\%20final /Tenzin\% 20pdf\% 2002. pdf (February 1, 2008)

Pan, X. and Sano, Y. (2005). Fraction of wheat straw by atmospheric acetic acid. Biores. Technol., 96: 12561263

Short, J.C.P., Frederickson, J., and Morris, R.M. (1999). Evaluation of traditional windrow composting and vermicomposting for the stabilization of waste paper sludge (WPS). Pedobiologia, 43:735-743

Singh, J., Kaur, A., Vig, A.P., and Rup, P.J. (2010). Role of Eisenia fetida in rapid recycling of nutrients from bio sludge of beverage industry. Ecotoxicol. Environ. Saf., 73:430-435

Singh, N.B., Khare, A.K., Bhargava, D.S., and Bhattacharya, S. (2005). Effect of initial substrate $\mathrm{pH}$ on vermicom- posting using Perionyx excavatus (Perrier, 1872). Appl. Ecol. Environ. Res., 4(1):85-97

Singh, K., Nath, G., Rai, R., and Shukla, R.C. (2013). Food preference of Eisenia foetida among different combinations of animal dung and agro/kitchen Wwstes. Bot. Resear. Int., 6(1): 23-26

Steven, J.F., Tha1, S., W., and Johan, S. (2009). Earthworm populations in relation to soil organic matter dynamics and management in California tomato cropping systems. App. Soil. Ecol., 41:206-214

Suramaythangkoor, T. and Gheewala, S.H. (2008). Potential of practical implementation of rice straw-based power generation in Thailand. Energy Pol., 36:3193-3197

Suthar, S., Watts, J., Sandhu, Rana, M., Kanwa, 1.S., Gupta, A.D., and Meena, M.S. (2005). Vermicomposting of kitchen waste by using Eisenia fetida (Savigny). Asian. J. Micro. Biotechnol. Environ. Sci., 7:541-544

Suthar, S. (2007). Influence of different food sources on growth and reproduction performance of composting Epigeics: Eudrilus Eugeniae, Perionyx Excavatus and Perionyx Sansibaricus. App. Ecol. Env. Res., 5(2):7992

Suthar, S. (2009). Nutrient changes and biodynamics of epigeic earthworm, Perionyx excavatus (Perrier) during recycling of some agricultural wastes. Bioresource. Tech., doi.10 1016/j.biotech.

Tripathi, G. and Bhardwaj, P. (2004). Comparative studies on biomass production, lifec ycles and composting efficiency of Eisenia foetida (Savigny) and Lampito mauritii (Kinberg). Biores. Technol., 92:275-278

Viji, J. and Neelanarayanan, P. (2016). Vermicomposting of sunflower (Helianthus annuus L.) Cob (pre-digested with Aspergillus niger) without cow dung by utilizing conventional composting earthworms. Int. J. Curr. Sci. Res., 2(5): 650-667

Vinotha, S.P., Parthasarathi, K., and Ranganathan, L.S. (2000). Enhanced phosphatise activity in earthworm casts is more of microbial origin. Curr. Sci., 79:11581159

Walkey, A. and Black, I.A. (1934). An examination of the degtjareff method for determining soil organic matter and prepared modification of the chronic acid titration method. Soil. Sci., 34: 29-38

Yadav, A. and Garg, V.K. (2010). Bioconversion of food industry sludge into value-added product (vermicompost) using epigeic earthworm Eiseniafetida. World Revi. Sci. Technol. Sust. Dev., 7(3):225-238 